\title{
Gait Disturbance
}

National Cancer Institute

\section{Source}

National Cancer Institute. Gait Disturbance. NCI Thesaurus. Code C78303.

A finding referring to walking difficulties. 